\title{
Self-efficacy, Self-esteem, and Subjective Happiness of Teacher Candidates at the Pedagogical Formation Certificate Program
}

\author{
Atilgan Erozkan ${ }^{1}$, Ugur Dogan $^{1}$, Arca Adiguzel $^{1}$ \\ ${ }^{1}$ Mugla Sitki Kocman University, Turkey \\ Correspondence: Ugur Dogan, Mugla Sitki Kocman University, Turkey
}

Received: April 9, 2016 Accepted: April 29, $2016 \quad$ Online Published: May 11, 2016

doi:10.11114/jets.v4i8.1535 URL: http://dx.doi.org/10.11114/jets.v4i8.1535

\begin{abstract}
This study investigated the relationship between self-efficacy, self-esteem, and subjective happiness. The study group is composed by 556 ( 291 female; 265 male) students who were studying at the pedagogical formation program at Mugla Sttk1 Kocman University. The data were collected by using the General Self-Efficacy Scale-Turkish Form, Self-Confidence Scale, and Subjective Happiness Scale. Pearson product-moment correlation analysis was employed to study the relationship between self-efficacy, self-esteem, and subjective happiness; structural equation modeling was also used for explaining subjective happiness. Initiation, effort, and persistence subdimensions of self-efficacy and internal self-confidence and external self-confidence subdimensions of self-esteem were found to be significantly correlated to subjective happiness. A significant impact of initiation, effort, and persistence subdimensions of self-efficacy and internal self-confidence and external self-confidence subdimensions of self-esteem on subjective happiness was detected. The theoretical implications of the link between self-efficacy, self-esteem, and subjective happiness were discussed.
\end{abstract}

Keywords: self-efficacy, self-esteem, subjective happiness, pedagogical formation program students

\section{Introduction}

Self-efficacy is a phenomenon related to whether or not an individual is capable of producing certain actions. To put differently, it is controlling one's life (Bandura, 1986, 1997). Bandura (1997) suggests that beliefs related to efficacy differ depending on factors such as (a) evaluation of current capacities, (b) perceived hardness of the act, (c) amount of attempt required, (d) amount of external support required, (e) situation in which the acts are accomplished, (f) temporal designs of achievements and failings and $(\mathrm{g})$ the way experiences are organized and reconstructed. He identifies the characteristics of self-efficacy as (a) the capacity to understand, (b) the capacity to anticipate, and (c) the capacity to manage the environment, oneself, and others. Self-efficacy differentiates depending on how individuals think, feel and act. It relies on an optimistic belief of being capable of coping with many stress factors. While individuals with high self-efficacy prefer to exercise more challenging tasks, low level of self-efficacy is associated with depression, anxiety, and helplessness.

According to Skaalvik and Skaalvik (2010), self-efficacy is an agent related to individuals' perceptions about their capacity in carrying out the roles prescribed for them in order to achieve a set of goals and objectives. Individuals with high level of self-efficacy adopt a "can-do" approach towards life and hence, they are able to perceive challenges as problems to be solved, rather than threats to be avoided (Graham, 2011). They are also able to set goals for themselves and commit themselves to achieving to these goals. Due to the fact that they are highly attached to life, those with high level of self-efficacy enjoy life. In case when they encounter problematic situations, they become self-confident due to their belief in their capability (Luszczynska, Gutiérrez-Doña, \& Schwarzer, 2005; Pajares, \& Urdan, 2006). On the other hand, individuals with low level of self-efficacy usually approach to a difficult task with fear. Furthermore, low self-efficacy becomes a cycle, such that; absence of belief in ability results in lack of action, which then increases self doubt. People with low self-efficacy doubt their own potential, have a tendency to stress out easily and are more depressed as compared to those with high self-efficacy level (Luszczynska, Schwarzer, Lippke, \& Mazurkiewicz, 2011; Rodebaugh, 2006). In a study, Sanna (1977) suggested that individuals with high self-efficacy level were more capable of bringing solutions and had more experience in accomplishing tasks successfully, than those with low self-efficacy level. When the capability of individuals with high self-efficacy to cope with stressful situations is considered, the 
positive relationship between self-efficacy, subjective well-being, and life satisfaction becomes evident (Lippke, Wiedemann, Ziegelmann, Reuter, \& Schwarzer, 2009; Salvador \& Mayoral, 2011).

Self-esteem is the most significant factor playing a vital role in an individual's mental health. And it is said to be significantly related to quality of life and physical and mental well-being (Mechanic, McAlpine, Rosenfield, \& Davis, 1994, cited in Carr \& Browne, 2015). However, no sufficient understanding has been developed with regards to this phenomenon outside this field. Self-esteem is defined as the competence and capability of an individual to cope with life's challenges and being worthy of happiness. Many definitions of self-esteem comprise subjective beliefs related to personal worth (Hendricks et al., 2001). One definition provided by Coopersmith (1981) includes the individuals' personal judgements of values or the attitudes with regards to self-worth. One of the most commonly accepted definitions of self-esteem is suggested by Rosenberg (1979), where it is presented as the individual's global positive or negative attitude towards self; he considers this phenomenon as a global attitude which demonstrates the psychological well being. There is also significant evidence in the literature supporting that the assessment of global self-esteem does not always reflect behaviour (Rosenberg, 1989). Self-esteem is not considered as an indicator of specific health actions; however, its attributes are stable and may continue in the adulthood (Kawash, 1982). Self-esteem is a complex personal concept with many influencing factors. And it is a basic human characteristic which addresses the capacity of human being for the aim of increasing their sense of self-worth by means of coping mechanisms (Johnson, 2012; Kilic, Sokmen, \& Ada, 2013; Rosenberg, Schooler, Schoenbach, \& Rosenberg, 1995).

The state of well-being becomes problematic where individuals are prevented from enhancing their self-esteem. Self-esteem includes both cognitive and affective aspects. While combination of components such as self-confidence and self-depreciation plays a significant role in the formation of the concept of self-esteem, the central focus of self-esteem is established via self-acceptance or self-respect. Regarding self-esteem, it is considered that the individual has an inherent value and that he/she will experience friendship, love, and happiness. It is the individual's perception that he/she deserves the respect of other people; that his/her well-being is worth supporting, protecting and nurturing. In addition, components of self-efficacy and self-respect play a significant role in a healthy self-esteem (Orth \& Robbins, 2014; Raboteg-Saric \& Sakic 2014; Rosenberg, Schooler, Schoenbach, \& Rosenberg, 1995; Yap, \& Baharudin, 2015).

There is a strong connection between self-esteem and happiness due to the facts that high level of self-esteem leads to happy and productive lives and that it is a direct predictor of happiness (Baumeister, Campbell, Krueger, \& Vohs, 2003). Past studies suggest that there is a direct proportion between the level of self-esteem and happiness (Santos et al. 2012; Santos et al. 2014). On the other hand, depending on the circumstances, low level of self-esteem is known to have a tendency to result in depression. Perspectives of many studies varied regarding the aforementioned relationship, some of which supported the buffer hypothesis. Some other studies suggested that self-esteem reduced the effects of stress. On the other hand, there were also opposite conclusions such that; while certain studies indicated that the negative effects of low self-esteem were mostly felt in good times, other studies supported the positive outcomes of high self-esteem, regardless of stress and other conditions (Baumeister, Campbell, Krueger, \& Vohs, 2003). Theories of subjective well-being which assessed the individual's own evaluations regarding emotional well-being and happiness included approaches such as affective, cognitive, and subjective happiness (Lyubomirsky \& Lepper, 1999). While the affective approach requires the measurement of positive and negative affect over a particular period of time, cognitive approach involves the judgement of overall life quality and satisfaction. However, the "subjective happiness" approach aims to find out whether the individual is happy or unhappy within the framework of a global and subjective assessment. Lyubomirsky and Lepper (1999) emphasized that a person -although having an average life- might consider himself a happy person, whereas he might also consider himself an unhappy person despite having been pleased, proud, and particularly excited within the previous month.

Happiness is defined as the mental or emotional state of well-being occurring as the result of positive emotions including contentment and joy. For the aim of defining happiness and its source, many biological, psychological, religious, and philosophical approaches have been presented. In order to implement a scientific method for finding answers to what "happiness" is and how it is achieved, numerous research groups including positive psychology conducted various studies. Happiness is a vague concept which can mean different things to different people. One of the most challenging aspects of the science dealing with happiness is to identify its different concepts and determine the components of these concepts which may be listed as well-being, quality of life, and flourishing (Diener, 2000; Shin \& Johnson, 1978).

From a subjective perspective, happiness can mean different things. Fundamentally, happiness means emotional well-being used to identify an individual's subjective state of well-being (Diener, Scollon, \& Lucas, 2003). Diener (2000) suggests that well-being is associated with the individuals' evaluations of their own lives. Basically, happiness is constructed on the individual's subjective evaluation of his life within the framework his sentiments and emotional outcome. 
Hence, it may be stated that life satisfaction (Simsek, 2009) and quality of life (Diener, 2000; Shin \& Johnson, 1978) are factors to be considered with regards to the relation of the concept of happiness with subjective well-being. As stated before, happiness is a concept which has different meanings to different people; however, most people agree on the term "glow" (Parducci, 1995) which refers to a pervasive and lasting sense that life is fulfilling, meaningful, and pleasant (Myers, 1992). Having conducted researches on this abstract structure, authors reached to an agreement regarding how this concept should be assessed and defined. Diener and his colleagues who referred to the concept as subjective well-being suggested a widely accepted definition: a combination of life satisfaction (a cognitive judgment) and the balance of the frequency of positive and negative affect (i.e., hedonic tone) (Diener, Larsen, Levine, \& Emmons, 1985).

Having originated from the positive psychology movement (Seligman \& Csikszentmihalyi, 2000), the concept of subjective happiness was suggested to be the balance of positive-negative effect, overall life satisfaction (Diener, 2000) and psychological state of well-being, joy, and contentment (Lyubomirsky, 2001). Subjective happiness involves both emotional and cognitive aspects, where the emotional aspect is divided into positive affect and lack of negative affect and the cognitive one is referred to as the life satisfaction. People with higher subjective happiness level tend to have more positive thoughts about themselves (Campbell, 1981; Lee \& Im, 2007), have more control over their personality (Larson, 1989), consider their past experiences as pleasant (Matlin \& Gawron, 1979) and react to positive events in a more emotional manner; however, they are less long lasting on the face of negative experiences (Seidlitz, Wyer, \& Diener, 1997). Hence; subjective happiness is frequently seen as among the components of a good life (Diener, Scollon, \& Lucas, 2003). Holding together with the statements above, Veenhoven (2007) suggested: "happiness is the degree to which a person evaluates the overall quality of his present life-as-a-whole positively and denotes an overall evaluation of life" (cited in Akin, 2014).

In consideration of the significant data related to self-efficacy, self-esteem, and subjective happiness, the aim of this research is to investigate whether there is significant relationship between self-efficacy, self-esteem, and subjective happiness and to present useful evidence towards predicting subjective happiness among young adults.

\section{Method}

\subsection{Research Model}

This study is a quantitative and relational study aimed at examining the relationship between self-efficacy, self-esteem, and subjective happiness.

\subsection{Participants}

The participants in the study were 556 (291 female; 265 male; $M=25.17$ years, $S D=2.90$ ) randomly selected students who were studying at the pedagogical formation program -Turkish Language and Literature, History, Mathematics, English Language Literature, Contemporary Turkish Dialects and Literatures, Sociology, and Philosophy departmentsat Mugla S1tk1 Kocman University.

\subsection{Instruments}

The data were collected by General Self-Efficacy Scale-Turkish Form (Yildirim \& Ilhan, 2010), Self-Confidence Scale (Akin, 2007), and Subjective Happiness Scale (Akin \& Satici, 2011).

\subsubsection{General Self-efficacy Scale-Turkish Form (GSES)}

A 17 item scale developed by Sherer and Adams (1983) was used to measure the self-efficacy level of young adults, which was adapted to Turkish by Yildirim and Ilhan (2010). Based on a five point Likert scale ranging from 1 'strongly not describe' to 5 'strongly describe', the samples are required to provide answers to the question 'how much do the following statements describe you?' The scale comprised a three factor structure which measured different aspects of self-efficacy such as initiation, effort and persistence. In the scale, 11 items in 17 are reverse coded and the total score ranges between 17 and 85. Any increase in the total score of the participant is directly proportional to the increase in his/her general self-efficacy level (Sherer \& Adams, 1983). As for the adaptation of the scale into Turkish, the Cronbach's alpha internal consistency coefficient was .80, Guttman split-half coefficient was .77 and test-retest Pearson correlation coefficient was .69 (Yildirim \& Ilhan, 2010), which reflected high reliability levels. Cronbach's alphas calculated in this study were $.81, .79$, and .73 .

\subsubsection{Self-confidence Scale (SCS)}

It is a scale developed by Akin (2007) comprising 33 items in a five point Likert scale. This scale is composed of two subscales; namely internal self-confidence and external self-confidence. While internal self-confidence was a subscale comprising 17 items where the factor loads were between .31 and .74 and which explained $26.4 \%$ of the total variance, external self-confidence comprised 16 items with factor loads ranging between .32 and .75 which explained \% 17.2 of 
total variance. Fit index values of the scale were as follows: $\mathrm{RMSEA}=.044, \mathrm{NFI}=.90, \mathrm{CFI}=.96, \mathrm{IFI}=.96, \mathrm{RFI}=.89$, $\mathrm{GFI}=.94$, AGFI $=.91$, and SRMR $=.05$. The correlation between SCS and the Coopersmith Self-Esteem Inventory (Coopersmith, 1967) is $r=.87$. While the coefficients of internal consistency reliability for the whole scale, for the internal self-confidence and for the external self-confidence were found to be $.83, .83$ and .85 respectively, coefficients of test-retest reliability correlation for the whole scale, for internal self-confidence and for external self-confidence were $.94, .97$ and .87 . Furthermore, the scale's item-total correlations were found to have ranged between .30 and .72 . In this study, the Cronbach's alpha for internal and external self-confidence were calculated as .91 and .85, respectively.

\subsubsection{Subjective Happiness Scale (SHS)}

Subjective Happiness Scale (Lyubomirsky \& Lepper, 1999) was used to measure the subjective happiness, of which the Turkish adaptation was made by Akin and Satici (2011). It is a self-report instrument composed of 4 items where each item was rated on a 7-point scale. It is a summative scale where item 4 is reverse scored. The level of subjective happiness is found by means of the summation of all answers, where the highest number reflects the highest level of subjective happiness. As the result of the confirmatory factor analysis, it was observed that the uni-dimensional model well conformed to the Turkish population $\left(\chi^{2} / \mathrm{df}=0.71, \mathrm{p}=0.49193\right.$, RMSEA=.000, NFI $=.99, \mathrm{CFI}=1.00$, IFI $=1.00$, $\mathrm{RFI}=.98, \mathrm{GFI}=1.00, \mathrm{AGFI}=.99$, and SRMR=.015). The coefficients of internal consistency reliability and three-week test-retest reliability were found .86 and .73 , respectively. Cronbach's alpha calculated within the scope of this study was .85 .

\subsection{Procedures}

A permit for data collection was obtained from the Dean's Office of Faculty of Education in Mugla Sitk1 Kocman University, and the data were gathered in the randomly selected departments and classes by researcher. Data collection procedure was carried out by providing young adults with the appropriate environment and sufficient time for answering the questions in groups in the classroom.

\subsection{Data Analysis}

SPSS 18.00 (Statistic Program for Social Sciences) and the LISREL 8.80 package programs were used for the statistical analyses of the data. Within this context, Pearson product-moment correlation analysis and structural equation modelling were used for analysing the connection between self-efficacy, self-esteem, and subjective happiness. Structural equation modeling (SEM) is a statistical technique which uses the combination of statistical data and qualitative causal assumptions in order to test and estimate causal relations. The data analysis model is tested parallel to the measurement data available in order to find out to what extent the model fits the data. The causal assumptions which form the basis of this model may be verified by means of being tested against the data. Among the strengths of SEM, one of the most significant one is its capability to generate latent variables, which may not be directly measured but rather figured out from the previously measured variables, serving to reach the latent variables. This application provides certain benefits to the modeller such as the ability to observe the unreliability of measurement and the structural connections between the latent variables which must be considered accurately. Factor analysis, path analysis, and regression analysis demonstrate special cases of SEM (Grimm \& Yarnold, 2000; Kline, 2005; Sumer, 2000, cited in Erozkan, 2014). In this study, the model was constructed by means of testing the relationships between the variables of self-efficacy, self-esteem, and subjective happiness, using SEM.

The relationship between self-efficacy, self-esteem, and subjective happiness was tested by using Pearson correlation analysis and results are presented in Table 1.

Table 1. The Correlations between Subjective Happiness, Self-Efficacy, and Self-Esteem

\begin{tabular}{cccccc}
\hline & Initiation & Effort & Persistence & $\begin{array}{c}\text { Internal Self- External Self- } \\
\text { Confidence }\end{array}$ & Confidence \\
\hline Subjective Happiness & $.30^{*}$ & $.37 * *$ & $.39 * *$ & $.46 * *$ & $.40 * *$ \\
\hline$* p<.05 \quad * * p<.01$ & & & & &
\end{tabular}

Table 1 shows that subjective happiness is positively related to initiation, effort, and persistence subdimensions of self-efficacy, and internal self-confidence and external self-confidence subdimensions of self-esteem.

Structural equation modeling was performed to predict subjective happiness by subdimensions of self-efficacy and subdimensions of self-esteem and the results are given in Figure 1. Figure 1 illustrates the developed structural model (standardized coefficients). 


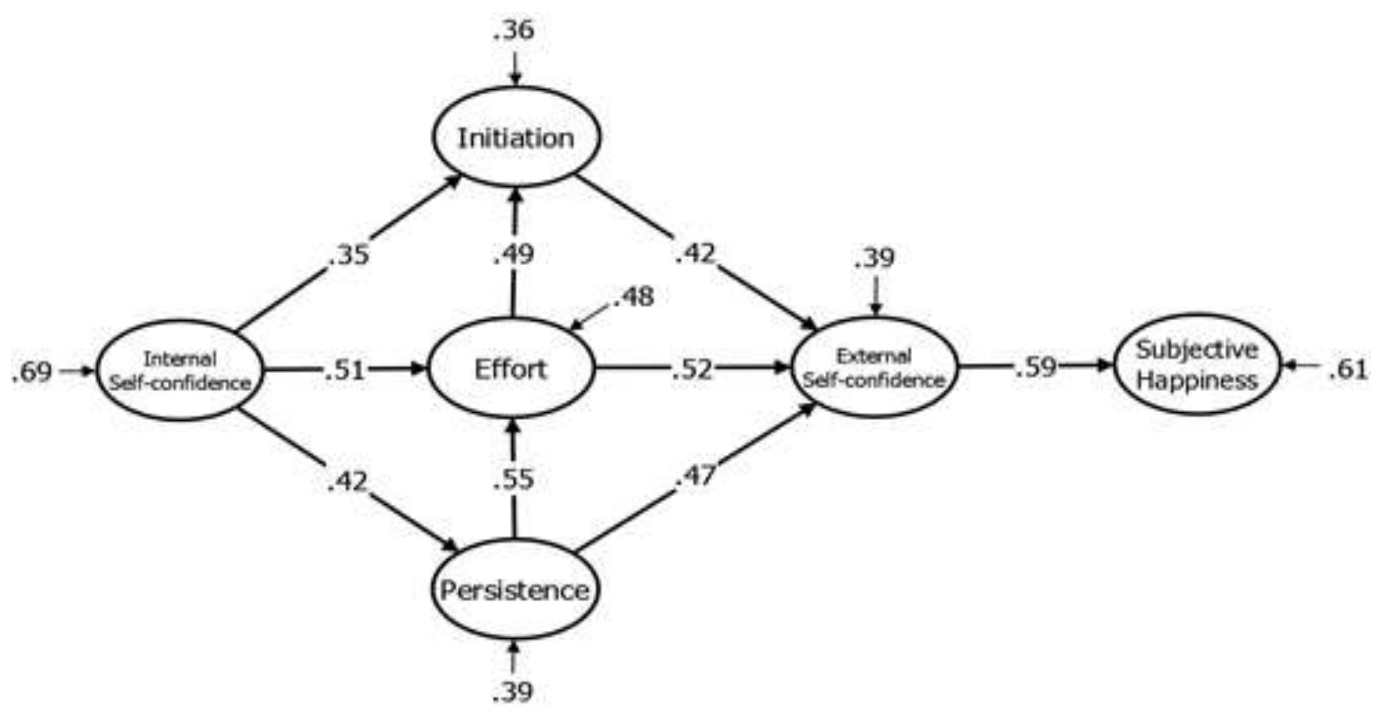

Figure 1. Path Diagram of Significant Predictors of Subjective Happiness

According to the data obtained the total points of subdimensions of self-efficacy and subdimensions of self-esteem predict the subjective happiness between .35 and .69. Figure 1 shows whether the variables are consistent or not is analyzed. As can be seen in Figure 1, the data obtained fit well model. The fitness coefficients related to the developed structural model are above the acceptable limits. For example, the value of NFI=.96, NNFI=.97, IFI=.97, CFI=.96, $\mathrm{GFI}=.93, \mathrm{AGFI}=.90, \mathrm{RMR}=.07 ; \mathrm{SRMR}=.06$, $\mathrm{RMSEA}=.04, \chi^{2}=528.29, \mathrm{df}=195$, and $\chi^{2} / \mathrm{df}=2.71$. These values indicate that the model is acceptable (Kline, 2005). Standardized path coefficients were used to explain the effect of the independent variables -subdimensions of self-efficacy and subdimensions of self-esteem- on subjective happiness. Path coefficients ranged from .35 and .69. Path coefficients with absolute values less than .10 could indicate a "small effect", values around .30 could suggest a "typical effect" or "medium effect", and a "large effect" could be indicated by coefficients with absolute values $>.50$ (Kline, 2005, cited in Erozkan, 2014). In this study, all of these values were higher than .30 .

\section{Results and Discussion}

Results obtained in this study reflected significant positive connections between subjective happiness, initiation, effort, and persistence subdimensions of self-efficacy and internal self-confidence and external self-confidence subdimensions of self-esteem. These results suggested a direct proportion between the levels of initiation, effort, and persistence beliefs of self-efficacy and internal self-confidence and external self-confidence and the levels of subjective happiness. Namely, initiation, effort, and persistence beliefs of self-efficacy and internal self-confidence and external self-confidence increased, subjective happiness increased as well.

Several studies suggested a positive relation between subjective happiness, self-efficacy, and self-esteem (Cha, 2003; Cheng \& Furman, 2003a; DeNeve \& Cooper, 1998; Diener \& Diener, 1995; Lyubomirsky, Tkach, \& DiMatteo, 2006; Schimmack \& Diener, 2003). Within the scope of numerous scientific studies, the relationship between happiness and self esteem -considered as among the significant psychological aspects of happiness- are being examined. The aforementioned studies have demonstrated self-esteem as among the important precursors of happiness and suggested that it was directly proportional with happiness (DeNeve \& Cooper, 1998; Diener \& Diener, 1995; Lyubomirsky \& Lepper, 1999). In studies examining the connection between self-esteem which may also be referred to as the individual's self-satisfaction (Rosenberg, 1965) and happiness, it was revealed that there had been a positive and significant relationship between the two phenomena (Furnham \& Cheng, 2000; Lyubomirsky, Tkach, \& DiMatteo, 2006). Dogan, Totan, and Sapmaz (2013) came to a conclusion that emotional self-efficacy had an indirect effect on happiness via self-esteem, which is known to be a significant factor influencing the state of subjective well-being (Cha, 2003; Cheng \& Furman, 2003b; Schimmack \& Diener, 2003). Generally, people with high self-esteem levels appear to be individuals who are more self-confident (Sahranavard \& Hassan, 2012), who do not consider the constraints of life as obstructions and who are more likely to welcome new life styles and ideas, along with their ability of self realization. Within this scope; due to the fact that they are happier and satisfied, people with high self-esteem levels also have higher levels of well-being.

While Diener, Scollon, and Lucas (2003) revealed a significant connection between self-esteem and subjective well-being, Schimmack and Diener (2003) suggested in their research conducted at the University of Illinois which comprised 141 college students that self-esteem was a significant indicator of subjective well-being. It was also stated 
by Bandura (1997) that the direct path linking efficacy beliefs in managing positive affect to happiness also verified that the self-efficacy beliefs were among the main indicators of the effective individual functioning.

It has been observed that individuals with high levels of self-esteem generally had low risks of anxiety and depression and demonstrated healthy outcomes (Baumeister, 1993; Greenberg et al., 1992). Furthermore, individuals with a certain extent of self-esteem are known to implement more effective strategies in terms of achieving their objectives, less likely to give up pursuing their goals when they face difficulties (Kernis \& Waschull, 1995) and appear to be more in control (Tedeschi \& Norman, 1985) compared to those with lower self-esteem levels. Despite the fact that some researchers reached a mutual understanding that the terms happiness and self-esteem meant the same, it should be noted that self-esteem is generally used as a term which refers to global happiness or psychological well-being (Baruch \& Barnett, 1986; Ryff, 1989; Whitley, 1985). Furthermore, it is commonly accepted that these terms are so closely connected that it is almost impossible to distinguish these two concepts. In addition, the concept of happiness is impossible to achieve without a certain level of self-confidence and self-acceptance.

Results obtained from the studies demonstrate that mental and physical health may be improved via happiness (Myers, 2000; Peterson, 2000). In general, happy individuals are not only likely to react to events and conditions more positively and be capable of accepting these conditions, but also have less stress and a stronger immune system compared to unhappy individuals (Lyubomirsky, Sheldon, \& Schkade, 2005). As Bandura (1994) stated: "self-efficacy is people's belief in their capacity to exercise some measure of control over environmental events." Furthermore, it was also proved that self-efficacy developed an individual's way of thinking and brought out his motivations and behaviour. Expectations regarding self-efficacy are judgments about how positively a person can act in a certain way in order to meet an objective or cope with problematic situations (Bandura, 1997).

Veenhoven (2007) considers that there are many variables for achieving to happiness. Many researchers suggest that there is a strong relationship between high self-efficacy and the state of well-being, stress control, high self-esteem, healthier physical conditions, adaptation, and healing up (Bandura, 1997; Bisschop, Kriegsman, Beekman, \& Deeg, 2004; Kuijer \& de Ridder, 2003). As for Diener, the state of well-being is a subjective experience related to the quality of life and emotional stress which the individual perceives, evaluates and reports (Diener, 1984; 1994; 2000; Diener, Lucas, \& Oishi, 2002; Diener, Suh, Lucas, \& Smith, 1999). Subjective well-being is the way an individual evaluates life satisfaction (Lai, 2015; Lai, Cummins, \& Lau, 2013; Robbins \& Kliewer, 2000). Diener, Emmons, Larson, and Griffin (1985) define life satisfaction as a cognitive judgemental process where a person evaluates his quality of life.

While it is commonly accepted that there is a strong relationship between high self-efficacy and the state of well-being, stress control, high self-esteem, healthier physical conditions, adaptation and healing up (Bandura, 1997; Bisschop, Kriegsman, Beekman, \& Deeg, 2004; Kuijer \& de Ridder, 2003); low self-efficacy is known to be related to symptoms of anxiety and depression (Faure \& Loxton, 2003; Kashdan \& Roberts, 2004; Shnek, Irvine, Stewart, \& Abbey, 2001), and also low subjective well-being state (Bandura, Caprara, Barbaranelli, Gerbino, \& Pastorelli, 2003; Barlow, Wright, \& Cullen, 2002; Caprara, 2002). Savi Cakar (2012) emphasized that people with high self-efficacy levels were more likely to be comfortable and productive when they encounter difficult work conditions compared to individuals with low self-efficacy levels who perceive tasks as harder than what they actually are. Due to the fact that it limits their perspective, people with such a perception are likely to suffer from high levels of stress and anxiety (Pajares, 2002). Within this scope, Dora (2003) emphasized that individuals are required to cope with problems for attaining happiness and satisfaction in life. It is the individual's level of self-efficacy which determines psychological well-being (Magaletta \& Oliver, 1999) and psychological harmony (Cutler, 2005). In young adults, high self-efficacy levels may help improve the activity levels and their contentment with regards to themselves and other conditions (Savi Cakar, 2012). From this perspective, believing the self-potential to control the events or; in other words self-efficacy may increase subjective well-being.

The frequency and degree of positive affect or joy, the average level of satisfaction over a period and the absence of negative feelings, such as depression and anxiety are the three components which Argyle and Crossland (1987) consider to be comprised by happiness. Furthermore, happiness is also considered to be related to other life areas such as self-esteem (Cheng \& Furnham 2003a, 2003b; Hills \& Argyle, 2002; Rosenberg, Schooler, Schoenbach, \& Rosenberg, 1995), optimistic view and hope for the future (Abdel-Khalek, 2006; Brebner, Donaldson, Kirby, \& Ward, 1995; Magaletta \& Oliver, 1999), effective handling of the problems in life (Suldo \& Huebner, 2004), success in career (Boehm \& Lyubomirsky, 2008) and fewer problems of physical health (Natvig, Albrektsen, \& Qvarnstrøm, 2003). Positive attitudes and judgements of happier individuals provide them with the ability to maintain their positive moods when they encounter with the problems of life (Lyubomirsky \& Tucker, 1998; Lyubomirsky, 2001).

\section{Conclusion}

In current study, it was found that there was a positive relationship between self-esteem and self-efficacy are on 
individuals' happiness. Self-esteem and self-efficacy were associated with happiness in young adults. This study also revealed that self-esteem and self-efficacy significantly explains happiness. All the findings given above provide evidence with regards to how significant self-esteem and self-efficacy are on individuals' happiness. However, these suggestions must be further examined.

\section{Limitations}

Furthermore, this study comprised certain limitations such as the modesty and convenience of the sample group which was composed of undergraduates only from the Mugla Sitk1 Kocman University in Mugla city. Hence, data obtained may not be generalized and larger samples from various cities must be selected in further studies. In addition, the causal conclusions appear to be less convincing due to the study's cross-sectional nature; thus, a longitudinal approach may contribute to our understanding of causal relationships between self-esteem, self-efficacy, and happiness. Despite these limitations, it was observed that the indicators used were appropriate, demonstrating that the proposed theory was consistent with our data. So, this research may be considered to have contributed to our knowledge regarding the basis of subjective happiness.

\section{References}

Abdel-Khalek, A. M. (2006). Measuring happiness with a single-item scale. Social Behavior and Personality, 34(2), 139-150. http://dx.doi.org/0.2224/sbp.2006.34.2.139

Akin, A. (2007). The development of self-esteem scale: Psychometric properties. Abant Izzet Baysal University Faculty of Education Journal, 7(2), 167-176.

Akin, A., \& Satici, S. A. (2011). Subjective happiness scale: A study of validity and reliability. Sakarya University Journal of Education Faculty, 21, 65-77.

Akin, U. (2014). Does authenticity predict subjective happiness of Turkish teacher candidates. Journal of Educational and Instructional Studies in the World, 4(2), 48-54.

Argyle, M., \& Crossland, J. (1987). The dimensions of positive emotions. British Journal of Social Psychology, 26(2), 127-137. http://dx.doi.org/10.1111/j.2044-8309.1987.tb00773.x

Bandura, A. (1986). Social foundations of thought and action: a social cognitive theory. Englewood Cliffs, NJ: Prentice Hall.

Bandura, A. (1994). Self-efficacy. In V. S. Ramachaudran (Ed.), Encyclopedia of Human Behavior (Vol. 4, pp. 71-81). New York: Academic Press.

Bandura, A. (1997). Self-efficacy: The exercise of control. New York: Freeman.

Bandura, A., Caprara, G. V., Barbaranelli, C., Gerbino, M., \& Pastorelli, C. (2003). Role of affective self-regulatory efficacy in diverse spheres of psychosocial functioning. Child Development, 74(3), 769-782. http://dx.doi.org/10.1111/1467-8624.00567

Barlow, J., Wright, C., \& Cullen, L. (2002). A job-seeking self-efficacy scale for people with physical disabilities: Preliminary development and psychometric testing. British Journal of Guidance and Counselling, 30(1), 37-53. http://dx.doi.org/10.1080/030698880220106500

Baruch, G. K., \& Barnett, R. C. (1986). Role quality, multiple role involvement, and psychological well-being in midlife women. Journal of Personality and Social Psychology, 51(3), 578-585. http://dx.doi.org/10.1037/0022-3514.51.3.578

Baumeister, R. F. (1993). Self-esteem: The puzzle of low self-regard. New York: Plenum.

Baumeister, R. F., Campbell, J. D., Krueger, J. I., \& Vohs, K. D. (2003). Does high self-esteem cause better performance, interpersonal success, happiness, or healthier lifestyles? Psychological Science in the Public Interest, 4(1), 1-44. http://dx.doi.org/10.1111/1529-1006.01431

Bisschop, M. I., Kriegsman, D. M. W., Beekman, A. T. F., \& Deeg, D. J. H. (2004). Chronic diseases and depression: The modifying role of psychosocial resources. Social Science and Medicine, 59(4), 721-733. http://dx.doi.org/10.1016/j.socscimed.2003.11.038

Boehm, J. K., \& Lyubomirsky, S. (2008). Does happiness promote career success? Journal of Career Assessment, 16(1), 101-116. http://dx.doi.org/10.1177/1069072707308140

Brebner, J., Donaldson, J., Kirby, N., \& Ward, L. (1995). Relationships between happiness and personality. Personality and Individual Differences, 19(2), 251-258. http://dx.doi.org/0.1016/0191-8869(95)00022-X

Campbell, A. (1981). The sense of well-being in America: Recent patterns and trends. New York: McGraw-Hill. 
Caprara, G. V. (2002). Personality psychology: Filling the gap between basic processes and molar functioning. In C. von Hofsten and L. Bäckman (Eds.), Psychology at The Turn of The Millennium, Vol. 2: Social, Developmental, and Clinical Perspectives (pp. 201-224). Florence: Taylor and Francis/Routledge.

Carr, M., \& Browne, K. D. (2015). Measurement and conceptualisation of self-esteem with forensic clientele. Assessment \& Development Matters, 7(3), 20-22.

Cha, K. H. (2003). Subjective well-being among college students. Social Indicators Research, 62(1), 455-477. http://dx.doi.org/10.1023/A:1022669906470

Cheng, H., \& Furnham, A. (2003a). Attributional style and self-esteem as predictors of psychological well being. Counselling Psychology Quarterly, 16(2), 121-130. http://dx.doi.org/10.1080/0951507031000151516

Cheng, H., \& Furnham, A. (2003b). Personality, self-esteem, and demographic predictions of happiness and depression. Personality and Individual Differences, 34(6), 921-942. http://dx.doi.org/10.1016/S0191-8869(02)00078-8

Coopersmith, S. (1967). The antecedents of self-esteem. San Francisco: W. H. Freeman and Company.

Coopersmith, S. (1981). Adult form SEI Coopersmith inventory. Palo Alto, CA: Consulting Psychologists Press.

Cutler, C. G. (2005). Self-efficacy and social adjustment of patients with mood disorder. Journal of the American Psychiatric Nurses Association, 11(5), 283-289. http://dx.doi.org/10.1177/1078390305282335

DeNeve, K. M., \& Cooper, H. (1998). The happy personality: A meta-analysis of 137 personality traits and subjective well-being. Psychological Bulletin, 124(2), 197-229. http://dx.doi.org/10.1037/0033-2909.124.2.197

Diener, E. (1984). Subjective well-being. Psychological Bulletin, 95, 542-575.

Diener, E. (1994). Assessing subjective well-being: Progress and opportunities. Social Indicators Research, 31(2), 103-157. http://dx.doi.org/10.1007/BF01207052

Diener, E. (2000). Subjective well-being: The science of happiness and a proposal for a national index. American Psychologist, 55(1), 34-43. http://dx.doi.org/10.1037/0003-066X.55.1.34

Diener, E., \& Diener, M. (1995). Cross-cultural correlates of life satisfaction and self-esteem. Journal of Personality and Social Psychology, 68(4), 653-663. http://dx.doi.org/10.1037/0022-3514.68.4.653

Diener, E., Emmons, R. A., Larsen, R. J., \& Griffin, S. (1985). The satisfaction with life scale. Journal of Personality Assessment, 49(1), 71-75. http://dx.doi.org/10.1207/s15327752jpa4901_13

Diener, E., Larsen, R. J., Levine, S., \& Emmons, R. A. (1985). Intensity and frequency: Dimensions underlying positive and negative affect. Journal of Personality and Social Psychology, 48(5), 1253-1265. http://dx.doi.org/10.1037/0022-3514.48.5.1253

Diener, E., Lucas, R. E., \& Oishi, S. (2002). Subjective well-being: The science of happiness and life satisfaction. In C. R. Snyder and S. J. Lopez (Eds.), The Handbook of Positive Psychology (pp. 63-73). New York: Oxford University Press.

Diener, E., Scollon, C., \& Lucas, R. (2003). The evolving concept of subjective well-being. Advances in Cell Aging and Gerontology, 15, 187-219. http://dx.doi.org/10.1016/S1566-3124(03)15007-9

Diener, E., Suh, E. M., Lucas, R. E., \& Smith, H. L. (1999). Subjective well-being: Three decades of progres. Psychological Bulletin, 125(2), 276-302.

Dogan, T., Totan, T., \& Sapmaz, F. (2013). The role of self-esteem, psychological well-being, emotional self-efficacy, and affect balance on happiness: A path model. European Scientific Journal, 9(20), 31-42.

Dora, S. (2003). The adaptation of social problem-solving inventory (revised form) into Turkish: Validity and reliability studies. (Unpublished Master Thesis), Hacettepe University, Institute of Social Sciences, Ankara.

Erozkan, A. (2014). Analysis of social problem solving and social self-efficacy in prospective teachers. Educational Sciences: Theory and Practice, 14(4), 447-455. http://dx.doi.org/10.12738/estp.2014.2.2014

Faure, S., \& Loxton, H. (2003). Anxiety, depression and self-efficacy levels of women undergoing first trimester abortion. South African Journal of Psychology, 33(1), 28-38. http://dx.doi.org/10.1177/008124630303300104

Furnham, A., \& Cheng, H. (2000). Perceived parental behaviour, self-esteem and happiness. Social Psychiatry and Psychiatric Epidemiology, 35(10), 463-470. http://dx.doi.org/10.1007/s001270050265

Graham, S. (2011). Self-efficacy and academic listening. Journal of English for Academic Purposes, 10, 113-117.

Greenberg, J., Solomon, S., Pyszczynski, T., Rosenblatt, A., Burling, J., Lyon, D., Simon, L., \& Pinel, E. (1992). Why 
do people need self-esteem? Converging evidence that self-esteem serves an anxiety-buffering function. Journal of Personality and Social Psychology, 63(6), 913-922. http://dx.doi.org/10.1037/0022-3514.63.6.913

Grimm, L. G., \& Yarnold, P. R. (2000). Reading and understanding MORE multivariate statistics. Washington, DC,: American Psychological Association.

Hendricks, C. S., Tavakoli, A., Hendricks, D. L., Harter, N. R., Campbell, K. P., L'Ecuyer, R. I., Geddings, A. A., Hackett, D., Byrd, L., \& Mathis, D. (2001). Self-esteem matters: Racial and gender differences among rural southern adolescents. Journal of National Black Nurses' Association, 12(2), 15-22.

Hills, P., \& Argyle, M. (2002). The Oxford happiness questionnaire: A compact scale for the measurement of psychological well-being. Personality and Individual Differences, 33(7), 1073-1082. http://dx.doi.org/10.1016/S0191-8869(01)00213-6

Johnson, P. (2012). The prevalence of low self-esteem in an intellectually disabled forensic population. Journal of Intellectual Disability Research, 56, 317-325.

Kashdan, T. B., \& Roberts, J. E. (2004). Trait and state curiosity in the genesis of intimacy: Differentiation from related constructs. Journal of Social and Clinical Psychology, 23(6), 792-816. http://dx.doi.org/10.1521/jscp.23.6.792.54800

Kawash, G. F. (1982). A structural analysis of self-esteem from pre-adolescence through young adulthood: anxiety and extraversion as agents in the development of self-esteem. Journal of Clinical Psychology, 38(2), 301-311. http://dx.doi.org/10.1002/1097-4679(198204)38:2<301::AID-JCLP2270380212>3.0.CO;2-9

Kernis, M. H., \& Waschull, S. B. (1995). The interactive roles of stability and level of self-esteem: research and theory. In M. P. Zanna (Ed.), Advances in experimental social psychology (Vol. 27, pp. 93-141). San Diego, CA: Academic Press.

Kilic, D., Sokmen, Y., \& Ada, S. (2013). The relationship among self-efficacy, self-esteem and subjective well-being levels of prospective teachers. International Journal of Psycho-Educational Sciences, 4(4), 42-53.

Kline, R. B. (2005). Principles and practice of structural equation modeling (2nd ed). New York: Guilford Press.

Kuijer, R. G., \& de Ridder, D. T. D. (2003). Discrepancy in illness-related goals and quality of life in chronically ill patients: The role of self-efficacy. Psychology and Health, 18(3), 313-330. http://dx.doi.org/10.1080/0887044031000146815

Lai, L. (2015). Buddhism and subjective wellbeing: Do self-esteem, optimism and perceived control play a role? Open Journal of Social Sciences, 3(09), 1-7. http://dx.doi.org/10.4236/jss.2015.39001

Lai, L.C.H., Cummins, R.A., \& Lau, A.L.D. (2013). Cross-cultural differences in subjective wellbeing: Cultural response bias as an explanation. Social Indicators Research, 114(2), 607-619.

http://dx.doi.org/10.1007/s11205-012-0164-z

Larson, R. (1989). Is feeling "in control" related to happiness in daily life? Psychological Reports, 64(3), 775-784. http://dx.doi.org/10.2466/pr0.1989.64.3.775

Lee, J. Y., \& Im, G. S. (2007). Self-enhancing bias in personality, subjective happiness, and perception of life-events: A replication in a Korean aged sample. Aging Ment Health, 11(1), 57-60. http://dx.doi.org/10.1080/13607860600736265

Lippke, S., Wiedemann, A. U., Ziegelmann, J. P., Reuter, T., \& Schwarzer, R. (2009). Self-efficacy moderates the mediation of intentions into behavior via plans. American Journal of Health Behavior, 33(5), 521-529. http://dx.doi.org/10.5993/AJHB.33.5.5

Luszczynska, A., Gutiérrez-Doña, B., \& Schwarzer, R. (2005). General self-efficacy in various domains of human functioning: evidence from five countries. International Journal of Psychology, 40(2), 80-89. http://dx.doi.org/10.1080/00207590444000041

Luszczynska, A., Schwarzer, R., Lippke, S., \& Mazurkiewicz, M. (2011). Self-efficacy as a moderator of the planning-behaviour relationship in interventions designed to promote physical activity. Psychology and Health, 26(2), 151-166. http://dx.doi.org/10.1080/08870446.2011.531571

Lyubomirsky, S. (2001). Why are some people happier than others? The role of cognitive and motivational processes in well-being. American Psychologist, 56(3), 239-249. http://dx.doi.org/10.1037/0003-066X.56.3.239

Lyubomirsky, S., \& Lepper, H. S. (1999). A measure of subjective happiness: Preliminary reliability and construct validation. Social Indicators Research, 46(2), 137-155. http://dx.doi.org/10.1023/A:1006824100041 
Lyubomirsky, S., \& Tucker, K. (1998). Implications of individual differences in subjective happiness for perceiving, interpreting, and thinking about life events. Motivation and Emotion, 22(2), 155-186. http://dx.doi.org/10.1023/A:1021396422190

Lyubomirsky, S., Sheldon, K. M., \& Schkade, D. (2005). Pursuing happiness: The architecture of sustainable change. Review of General Psychology, 9(2), 111-131. http://dx.doi.org/10.1037/1089-2680.9.2.111

Lyubomirsky, S., Tkach, C., \& DiMatteo, M. R. (2006). What are the differences between happiness and self-esteem? Social Indicators Research, 78(3), 363-404. http://dx.doi.org/10.1007/s11205-005-0213-y

Magaletta, P. R., \& Oliver, J. (1999). The hope construct, will, and ways: Their relations with self - efficacy, optimism, and general well - being. Journal of Clinical Psychology, 55(5), 539-551. http://dx.doi.org/10.1002/(SICI)1097-4679(199905)

Matlin, M. W., \& Gawron, V. J. (1979). Individual differences in pollyannaism. Journal of Personality Assessment, 43(4), 411-412. http://dx.doi.org/10.1207/s15327752jpa4304_14

Mechanic, D., McAlpine, D., Rosenfield, S. \& Davis, D. (1994). Effects of illness attribution and depression on the quality of life among persons with serious mental illness. Social Science Medicine Journal, 39(2), 155-164.

Myers, D. G. (1992). The Pursuit of happiness. New York: William Morrow.

Myers, D. G. (2000). The funds, friends, and faith of happy people. American Psychologist, 55(1), 56-57. http://dx.doi.org/ 10.1037/0003-066X.55.1.56

Natvig, G. K., Albrektsen, G., \& Qvarnstrøm, U. (2003). Associations between psychosocial factors and happiness among school adolescents. International Journal of Nursing Practice, 9(3), 166-175. http://dx.doi.org/10.1046/j.1440-172X.2003.00419.x

Orth, U., \& Robbins, R.W. (2014). The development of self-esteem. Current Directions in Psychological Science, 23(5), 381-387.

Pajares, F. (2002). Gender and perceived self-efficacy in self-regulated learning. Theory Into Practice, 41(2), 116-125. http://dx.doi.org/10.1207/s15430421tip4102_8

Pajares, F., \& Urdan, T. (2006). Adolescence and education, Vol. 5: Self-efficacy beliefs of adolescents. Greenwich, CT: Information Age Publishing.

Parducci, A. (1995). Happiness, pleasure, and judgment: The contextual theory and its applications. Hillsdale, NJ, England: Lawrence Erlbaum Associates, Inc.

Peterson, C. (2000). The future of optimism. American Psychologist, 55(1), 44-55. http://dx.doi.org/10.1037/0003-066X.55.1.44

Raboteg-Saric, Z., \& Sakic, M. (2014). Relations of parenting styles and friendship quality to self-esteem, life satisfaction, and happiness in adolescents. Applied Research Quality Life, 9(3), 749-765. http://dx.doi.org/10.1007/s11482-013-9268-0

Robbins, S. B., \& Kliewer, W. L. (2000). Advances in theory and research on subjective well-being. In S. D. Brown and R. W. Lent (Eds.), Handbook of Counseling Psychology (3 ed., pp. 310-345). New Jersey: John Wiley and Sons Inc.

Rodebaugh, T. L. (2006). Self-efficacy and social behavior. Behaviour Research and Therapy, 44(12), 1831-1838.

Rosenberg, M. (1965). Society and the adolescent self-image. Princeton: Princeton University Press.

Rosenberg, M. (1979). Conceiving the self. Malabar, FL: Robert E. Krieger.

Rosenberg, M. (1989). Society and the adolescent self-image (rev. ed.). Middletown, CT, England: Wesleyan University Press.

Rosenberg, M., Schooler, C., Schoenbach, C., \& Rosenberg, F. (1995). Global self-esteem and specific self-esteem: different concepts, different outcomes. American Sociological Review, 60(1), 141-156. http://dx.doi.org/10.2307/2096350

Ryff, C. D. (1989). Happiness is everything, or is it? Explorations on the meaning of psychological well-being. Journal of Personality and Social Psychology, 57(6), 1069-1081. http://dx.doi.org/10.1037/0022-3514.57.6.1069

Sahranavard, M., \& Hassan, S. A. (2012). The relationship between self-concept, self-efficacy, self-esteem, anxiety and science performance among Iranian students. Middle-East Journal of Scientific Research, 12(9), 1190-1196.

Salvador, C., \& Mayoral, L. (2011). Entrepreneurial self-efficacy and life satisfaction in the ICT sector: A study of 
gender differences in argentina. Journal of Basic and Applied Scientific Research, 1(3), 242-251.

Sanna, L. J. (1997). Self-efficacy and counterfactual thinking: Up to a creek with or without a paddle. Personality and Social Psychology Bulletin, 23(6), 654-667. http://dx.doi.org/10.1177/014616729723600

Santos, M. C. J., Magramo Jr, C. S., Oguan Jr, F., \& Junnile, P. J. N (2014). Establishing the relationship between general self-efficacy and subjective well-being among college students. Asian Journal of Management Sciences \& Education, 3(1), 1-12.

Santos, M. C. J., Magramo Jr, C. S., Oguan Jr, F., Junnile Paat, J. N., \& Barnachea, E. A. (2012). Meaning in life and subjective well-being: is a satisfying life meaningful? Journal of Arts, Science \& Commerce, 4(1), 32-40.

Savi, C. F. (2012). The relationship between the self-efficacy and life satisfaction of young adults. International Education Studies, 5(6), 123-130. http://dx.doi.org/10.5539/ies.v5n6p123

Schimmack, U., \& Diener, E. (2003). Predictive validity of explicit and implicit self-esteem for subjective well being. Journal of Research in Personality, 37(2), 100-106. http://dx.doi.org/10.1016/S0092-6566(02)00532-9

Seidlitz Jr, L., Wyer, R. S., \& Diener, E. (1997). Cognitive correlates of subjective well-being: the processing of valenced life events by happy and unhappy persons. Journal of Research in Personality, 31(2), $240-256$. http://dx.doi.org/10.1006/jrpe.1997.2184

Seligman, M. E., \& Cikszentmihalyi, M. (2000). Positive psychology: An introduction. American Psychologist, 55(1), 5-14.

Sherer, M., \& Adams, C. H. (1983). Construct validation of the self-efficacy scale. Psychological Reports, 53(3), 899-902.

Shin, D. C., \& Johnson, D. M. (1978). Avowed happiness as an overall assessment of the quality of life. Social Indicators Research, 5(1), 475-492. http://dx.doi.org/ 10.1007/BF00352944

Shnek, Z. M., Irvine, J., Stewart, D., \& Abbey, S. (2001). Psychological factors and depressive symptoms in ischemic heart disease. Health Psychology, 20(2), 141-145. http://dx.doi.org/10.1037/0278-6133.20.2.141

Simsek, O. F. (2009). Happiness revisited: Ontological well-being as a theory-based construct of subjective well-being. Journal of Happiness Studies, 10(5), 505-522. http://dx.doi.org/10.1007/s10902-008-9105-6

Skaalvik, E. M., \& Skaalvik, S. (2010). Teacher self-efficacy and teacher burnout: A study of relations. Teaching and Teacher Education: An International Journal of Research and Studies, 26(4), 1059-1069.

Suldo, S. M., \& Huebner, E. S. (2004). Does life satisfaction moderate the effects of stressful life events on psychopathological behavior during adolescence? School Psychology Quarterly, 19(2), 93-105. http://dx.doi.org/10.1521/scpq.19.2.93.33313

Sumer, N. (2000). Structural equation modeling: Basic concepts and sample applications. Turkish Psychological Manuscripts, 3(6), 74-79.

Tedeschi, J. T., \& Norman, N. (1985). Social power, self-presentation, and the self. In B. R. Schlenker (Ed.), The self and Social Life (pp. 293-322). New York: McGraw-Hill.

Veenhoven, R. (2007). Measures of gross national happiness. Germany: University Library of Munich.

Whitley Jr, B. E. (1985). Sex-role orientation and psychological well-being: Two meta-analyses. Sex Roles, 12(1-2), 207-225. http://dx.doi.org/10.1007/BF00288048

Yap, S. T., \& Baharudin, R. (2015). The relationship between adolescents' perceived parental involvement, self-efficacy beliefs, and subjective well-being: A multiple mediator model. Social Indicators Research, 126(1), 257-278, http://dx.doi.org/10.1007/s11205-015-0882-0.

Yildirim, F., \& Ilhan, I. (2010). The validity and reliability of the General Self-Efficacy Scale-Turkish Form. Turkish Journal of Psychiatry, 21(4), 301-308.

\section{$(\mathrm{Cc}) \mathrm{BY}$}

This work is licensed under a Creative Commons Attribution 3.0 License. 